\title{
Problems of the Formation and Development of Terri- torial Public Self-Government: Sociological Analysis
}

\author{
Sergey Bozhenov ${ }^{1},{ }^{*}$ Evgeny Barkovsky ${ }^{1}$, Nikolay Danakin ${ }^{1}$, Elena Starostova ${ }^{1}$ \\ ${ }^{I}$ Belgorod State Technological University named after V.G. Shukhov, Russia \\ *Email: synergy7@mail.ru
}

\begin{abstract}
The article highlights actual problems of the formation and development of territorial public self-government (TPSG), which has become widespread in Russian regions. The results of applied sociological research conducted among residents and activists of TPSG in Belgorod are used. The following issues are identified and characterized, the unresolved question of which hinds the functioning and development of territorial public self-government. First of all, the population does not have an effective desire to participate in the organization and implementation of TPSG. There are significant number of negative and indifferent people (who find it difficult to define their own position). Territorial public self-government turns out to be an unappreciated institution for the development of civil initiatives. TPSG authorities have hierarchical dependence on local self-government authorities, therefore, they are often afraid of the administration, the emergence of subordinate relations. The problem - solving is possible on the basis of the development and implementation of a systemic development strategy of TPSG, which provides for a complex solution to financial, organizational, legislative and social issues.
\end{abstract}

Keywords: Territorial public self-government (TPSG), Problem, development, Municipal authorities, Municipal employee, Municipal management, Project management.

\section{INTRODUCTION}

The problems of the formation and development of territorial public self-government (TPSG) attract the attention of many researchers. So, Kuzmin M.I., based on an analysis of the practical activities of TPSG in different regions of Russia, highlights the main issues that territorial public self-government faces today. These are, first of all, incomprehension of the essence of TPSG, problems with legal registration of TPSG, low initiative of citizens in the creation of TPSG [1].

According to I.V. Mersiyanova, "the key characteristic of TPSG is the presence of the population's initiative, and the relations of self-organization and self-management are determinative" [2, p. 18-19]. At the same time, the development of territorial public self-government in many municipalities faces number of difficulties of both organizational, legal, informational, and individual psychological nature.
Everywhere there is unwillingness of the population to participate in the organization of territorial public selfgovernment, which is one of the main reasons for the weak development of this institution in our country. The ideology of individualism that has been instilled in the country for the past 20 years makes itself felt: many residents do not want to participate in public events. Repeated mention in the scientific literature that the problem of organizing public self-government in Russia today is directly related to the lack of citizens' "impulses for mutual support", experience of "successful collective actions" and "dialogue with other groups" at the level "Associations on problems and interests" [3, p. 24-39], reflects the emergence of new issues in the practice of state regulation of social processes, changing in their content and quality, based on new principles of organizing people's life activity. 


\section{MATERIALS AND METHODS}

The article was prepared based on the results: "Organ-
The presented distribution of responses outlines the potential contingent of residents, on which to rely in the formation of the TPSG system. This contingent is mainly

Table 1. Level of awareness of territorial public self-government depending on the age of respondents, in $\%$

\begin{tabular}{|l|l|l|l|l|l|l|}
\hline \multirow{2}{*}{ Variant of response } & \multicolumn{5}{|c|}{ Category of respondents } \\
\cline { 2 - 8 } & $\begin{array}{c}\text { Up to 29 years } \\
\text { old }\end{array}$ & $\begin{array}{c}30-39 \\
\text { years old }\end{array}$ & $\begin{array}{c}40-49 \\
\text { years old }\end{array}$ & $\begin{array}{c}50-59 \\
\text { years old }\end{array}$ & $\begin{array}{c}\text { Over } 60 \\
\text { years }\end{array}$ & Altogether \\
\hline 1. Yes & 42.16 & 54.97 & 63.64 & 68.93 & 60.50 & 56.30 \\
\hline 2. No & 53.31 & 36.84 & 33.94 & 27.12 & 38.00 & 39.60 \\
\hline 3. No response & 4.53 & 8.19 & 2.42 & 3.95 & 1.50 & 4.10 \\
\hline
\end{tabular}

ization of territorial public self-government"

- a sociological survey of residents of Belgorod: (1000 respondents were interviewed), conducted in 2016 by the Institute for Municipal Development and Social Technologies (Belgorod);

- sociological survey of TPSG assets "Actual problems of the development of territorial public self-government", conducted in 2019 by the Department of Sociology and Management of the Belgorod State Technological University named after Shukhov V.G. (150 respondents were interviewed).

Taking into account the socio-demographic composition of the general population, the quota indicators were gender, age, as well as the area of residence of the townspeople.

The handling of the survey was carried out with the aid of computer program using the methods of structural, comparative, factor analysis, grouping and typologization of assessment characteristics. The analysis of source information was carried out in accordance with the group of respondents by typological characteristics.

\section{RESEARCH RESULTS}

In this regard, the answers of the respondents to the question: "Are you ready to join the asset of your TPSG and represent the interests of the court in the Council of Territories?" which were distributed as follows (\%): yes - 21.2; more likely yes than no - 9.8; more likely no than yes - 19.2; no - 39.4; 9.2 - found it difficult to answer.

The general trend is that most of the respondents $(39.9 \%)$ would still under no circumstances want to engage in this activity. Moreover, even the availability of wealth is not able to change the position of citizens. More than half of those unwilling to be TPSG activists $(56.75 \%)$ are not ready to do this even if they are remunerated for such work, and only for $22.67 \%$ of respondents, the influence of wealth can make for a change in their decision. represented by the following social groups:

- budget workers with a high level of civic engagement and the need for additional earnings;

- those who are not employed in the city's economy, who feel the need to apply their organizational skills, Belgorod residents (but not the unemployed).

At the same time, the results of the survey state that the TPSG system is disconnected from the economically independent residents of the city, as well as young people under the age of 30 . Such isolation reveals the risk of giving the character of a local institution to the system of territorial public self-government. The threat of social localization of TPSG is especially relevant due to the fact that without its elimination the TPSG system cannot become a conductor of the ideas of the urban social community.

A necessary precondition and, at the same time, a "component" of willingness of people to participate in TPSG is its awareness of this form of self-organization of citizens.

Our sociological research in the city of Belgorod allows us to determine the degree of awareness of the population about this form of self-organization of citizens. The results of the survey show that $56.30 \%$ have heard about TPSG, while $39.60 \%$ of the respondents do not know anything about it.

Analysis of the answers to the question about the knowledge of TPSG depending on the sociodemographic characteristics of the respondents shows that:

a) awareness of TPSG is directly proportional to the age of the respondents: the older the respondents, the higher the level of awareness (Table 1);

b) women are more aware of TPSG $(60.11 \%)$ than men (51.84) [4].

This state of affairs is quite obvious: interest in TPSG is more pronounced in adults due to two main circumstances: 
- firstly, the forms of civil society were instilled in aged Belgorod residents even during the domination of the communist ideology;

- secondly, the modern TPSG system is aids at retirees and housewives, there are no forms of participation in TPSG that are convenient for busy people or interesting for young people [5].

Figure 1 shows the answers of Belgorod residents to the question about the level of awareness of TPSG depending on the type of occupation. Status groups are distributed in descending order: from the most informed to the least informed.

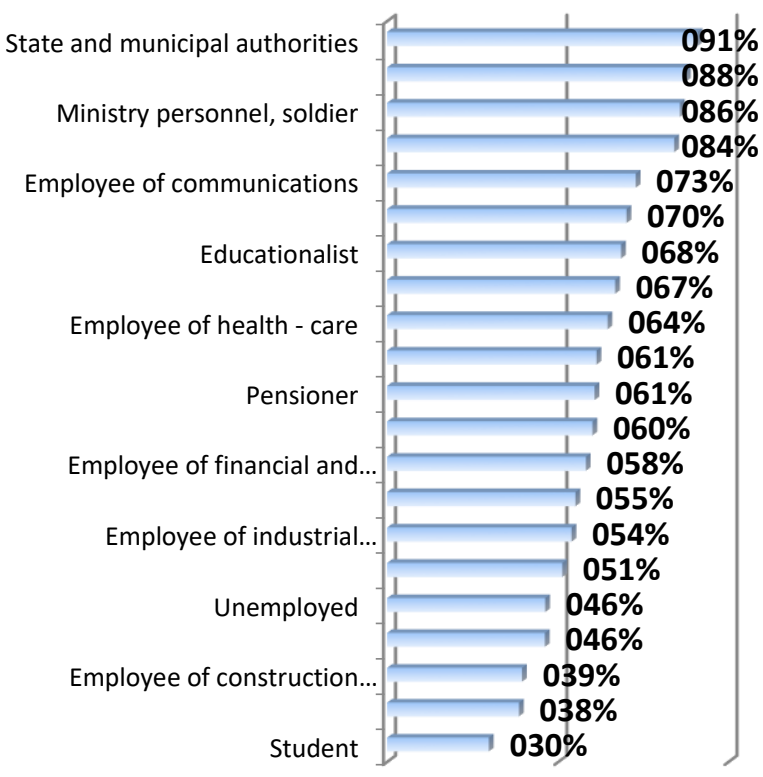

Figure 1 Level of awareness about territorial public self-government depending on the type of occupation of the respondents.

The reported data make it clear that employees of state and municipal authorities $(90.9 \%)$, employees of social protection institutions $(87.5 \%)$, military personnel, employees of the Ministry of Internal Affairs (85.7\%), cultural workers $(84.0 \%)$ know more about TPSG, i.e. groups of citizens, in one way or another, associated with the activities of the authorities.

Thus, the results of the survey clearly demonstrate the narrowness of information support for the activities of modern TPSG. With a certain degree of convention, it is possible to formulate a principle that characterizes such information support - this is the principle of "least resistance" (coverage of information "insiders").

An analysis of the awareness among citizens by geographical constituencies in the context of the identified residential zones shows the following situation: the awareness of the population about territorial public self- government is higher in areas of old buildings and, accordingly, lower in new areas of the city [6]. This state of affairs is not surprising, because Belgorod residents have been living in the areas of old buildings for more than a decade, so relations inside the courtyard are often in the nature of an open information exchange. On the contrary, in the new districts of the city, characterized by new infrastructure, high building density, a significant part of the residents are newcomers, who are more closed for communication with others, they are alien to the problems of the territories. The quality of social communication is influenced by the fact that in financial terms newcomers are more independent, therefore, in social terms, they are more atomistic.

The survey enables to assess the level of awareness of the existence of specific TPSG in the respondents' places of residence. To the question of the questionnaire: "Do you know if there is a TPSG in your yard?", Only $28.4 \%$ answered in the affirmative. More than half of Belgorod residents $(56.1 \%)$ do not know about it. Thus, it is necessary to note the lack of information's efficiency for the activities of more than half of TPSG in the city.

In continuing the analysis of social problems of TPSG development, let us turn to one more important factor, namely, trust. Figure 2 shows the distribution of the respondents' answers related to the level of their trust in the assets of the yard (chairman, TPSG council).

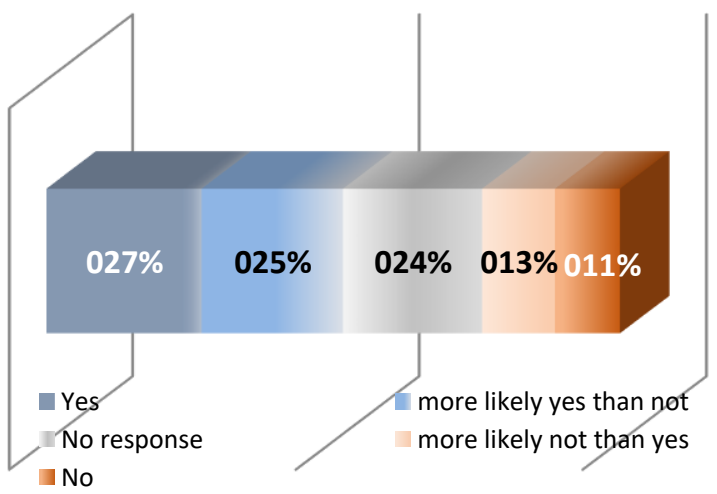

Figure 2 Distribution of responses to the question: "Are you ready to entrust the solution of issues of the territory to the asset of the yard (chairman, council of TPSG)?"

As can be seen from the reported data, more than half of the respondents $(51.4 \%)$ are more or less willing to trust an asset (26.9\% - certainly; $24.5 \%$ - more likely yes than not). Taking into account the problems of the information support of TPSG activities, the value of this indicator can be recognized as quite high.

The significant proportion of respondents could not decide on the answer $(24.1 \%)$ and answered "more likely not than yes" (12.6\%). The percentage of Belgorod residents who answered categorically "no" is relatively low and amounts to $11.2 \%$. This social group mostly includes 
people who are characterized by protest attitudes and rejection of new ideas. Such people in the city of Belgorod traditionally are $10-12 \%$

Public confidence in TPSG authorities is associated with the level of information transparency of their activities. The question of the openness of the TPSG Council for the residents of the courtyard, almost half of the respondents, caused difficulty (43.90\%) (figure 3).

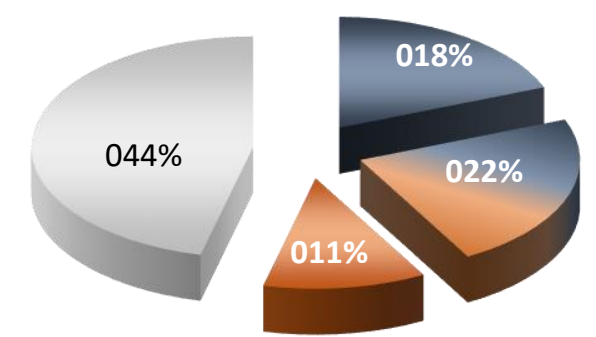

$\square$ Yes, quite $\square$ Not always $\square$ No $\square$ No response

Figure 3 Distribution of responses to the question: "Do you consider the activities of the TPSG Council sufficiently open for the residents of the yard?"

This is due to the fact that the population does not have a clear understanding of the activities of territorial public self-government, its functions and tasks. Therefore, it is imperative to show the main features of the emerging TPSG system to the population in order to make Belgorod residents understand the need for its creation. At the moment, most of the townspeople did not understand the openness of this system (43.9\%). In addition, it should be noted that only $18.1 \%$ consider the activities of the TPSG Council to be quite open.

The data confirms the thesis that there is a problem of ensuring to information on TPSG for all citizens. The capabilities of TPSG are closely related to the attitude towards this institution on the part of the population and local authorities. Considering that today the activity of the population is rather low, then the attitude of the authorities becomes decisive. But a close connection with the authorities, on the one hand, provides TPSG with guarantees of material and financial support, guarantees to be heard by the authorities, as well as the possibility of wide public recognition of the leaders of public self-government, and on the other hand, leads to political engagement of TPSG leaders which is not accepted by the population and causes distrust among citizens. "In addition, the leaders of the TPSG have difficulties entering a conflict with the authorities, if the interests of the development of territories demand it. In the long term, the focus on a guaranteed source of income leads to reduced demand for seeking additional investment, that is, just to decline in their economic activity, which is so expected from public organizations by authorities at all levels" [7].
At the same time, the lack of skills to political dialogue and understanding of TPSG role and place in the development of local self-government leads to many local conflicts between active leaders of TPSG and local self-government authorities. This became one of the reasons for the change in the concept of TPSG in Federal Law No. 131-FZ. In it, an effort was made to strike a balance between the two above - mentioned opposite positions: on the one hand, territorial public self-government was defined as the citizens self-organization at their place of residence (ie, community action groups); on the other hand, TPSG are directly dependent on local self-government authorities, which approve the boundaries and charter of TPSG, have the ability to involve TPSG in the provision of a number of municipal services (works), entrust TPSG with the implementation of a number of their functions, i.e., in fact significantly affect the organization and content of their activities [8, p. 154].

In the organization of TPSG, the influence of such a factor as formalism is clearly traced $[9, \mathrm{p} .8]$. The desire for achieve the coverage and improved rate contained in the above-mentioned federal normative legal acts, the authorities of municipalities go to the creation of TPSG on a "top-down" basis, without activating the initiative of the population of specific territories. The TPSG created in this way, as a rule, exists only on paper with no visible development prospects, without real levers of influence on local authorities.

\section{THE DISCUSSION OF THE RESULTS}

As noted researches [10], the authorities' powers represented by residents and their imaginary use do not correspond to the real tasks and mission of TPSG as a selforganization of the population, but is aimed at life support and provision of services instead of the state and the municipality. TPSG is essentially trying to compensate for the disfunctions and shortcomings of municipal services and governing authorities. But the better the municipal services work, the less will be the need for TPSG among city residents. There is a clear replacing the substance of territorial self-government for a demonstration of activity. In practice, this is what happens, the TPSG authorities respond to mandates of the regional administrations, which the TPSG authorities should not execute. For the same reason, many employees consider themselves representatives of the administration.

\section{CONCLUSION}

As a result of the survey, the following problems were identified and described that hinder the functioning and development of territorial public self-government, ensuring its effectiveness. 
- the problem of real participation of the population: the urban population has lack of clear motives for participate in the organization of territorial public self-government.

- the problem of trust: many city residents mistrust the "nearest" TPSG structures.

- the problem of increasing the social status of TPSG: territorial public self-government is not present in all municipalities.

- the problem of the territorial community's unwillingness for self-government: a significant part of Belgorod residents would not, under any circumstances, want to engage in this activity: even the presence of renumeration is not able to change the position of citizens.

- the problem of legal support: TPSG authorities are placed in a hierarchical dependence on local government authorities.

\section{REFERENCES}

[1] Kuzmin M.N. Monitoring as an integral part of information support of the management process, Mordovia State University named after N.P. Ogarev, 2009, No. 1.

[2] I.V. Mersiyanova, Approaches to problems of forming the social base of local self-government in strategic planning of the development of municipalities, Information and methodological materials for the XIX General Meeting of the Association of Siberian and Far Eastern Cities. Novosibirsk: Institute of the Non-Governmental Sector, 2003, pp. 18-19.

[3] L.D., Gudkov, B.V. Dubin, Necessary acquaintances: peculiarities in conditions of institutional deficits, Monitoring of public opinion: Economic and social changes 3(59) (2002) 24-39.

[4] Razvitie sistemy territorial'nogo obshhestvennogo samoupravlenija $\mathrm{v}$ gorode Belgorode: Informacionno-analiticheskij otchet po itogam sociologicheskogo issledovanija, pod red. V.A. Voronova. Belgorod: MAU «Institut municipal'nogo razvitija i social'nyh tehnologij», 2012.

[5] A.A. Tkachev, K.A. Khripkov, Sociological analysis of the self-governing potential of local communities, Modern Research of Social Problems, Iss. 9(29), 2013,

[6] R.I. Gaydukov, Factors of integration of territorial self-government, NOMOTHETIKA: Philosophy, Sociology, Right 2(121) 2012 212-217.

[7] L.G. Ragozina, Can territorial public self-government in Russia become a resource for the development of local initiatives? Practice of municipal management, Iss. 1.2012.
[8] I.V. Mersiyanova, Territorial public self-government as a form of public participation, Questions of state and municipal administration 3 (2010) 154.

[9] G.M. Samostroenko, A.A. Ovsyannikov, Strategic factors in the development of territorial public selfgovernment, Management of public and economic systems 1 (2011) 8 .

[10] V.A. Kornilovich, Territorial public self-government: problems of development and functioning [Electronic resource]. Retrieved from: http://www.np-nic.ru/publikatsii/filosofiya/13 